\title{
Gaps in nursing care for people with urinary incontinence
}

\section{As lacunas do cuidado de enfermagem às pessoas com incontinência urinária}

Las lagunas del cuidado de enfermería para las personas con incontinencia urinaria

Sarah Cristiane dos Reis', Thiago Suzano Oliveira', Eliza Maria Rezende Dázio 1,2, Roberta Seron Sanches 1,2, Jenika Ferreira Dias ${ }^{1,3}$, Silvana Maria Coelho Leite Fava ${ }^{1,2}$

ORCID IDs

Reis SC (D) https://orcid.org/0000-0002-2801-9032

TS Oliveira iD https://orcid.org/0000-0002-0782-8957

Dázio EMR (iD https://orcid.org/0000-0001-9216-6283

Sanches RS (iD https://orcid.org/0000-0001-7557-5560

Dias JF (iD https://orcid.org/0000-0002-2743-0751

Fava SMCL (iD https://orcid.org/0000-0003-3186-9596

\section{HOW TO CITE}

Reis SC, Oliveira TS, Dázio EMR, Sanches RS, Dias JF, Fava SMCL. Gaps in nursing care for people with urinary incontinence. ESTIMA, Braz. J. Enterostomal Ther., 16: e3618. https://doi.org/10.30886/estima. $\underline{\mathrm{V} 16.621 \mathrm{IN}}$

\begin{abstract}
Objective: To survey in the literature the role of the nurse in the care of people with urinary incontinence (UI). Methods: Integrative literature review from the publications within the period of 2013 in the databases: BDENF, LILACS, Web of Science, PubMed and SciELO, in the Portuguese, English and Spanish languages. The sample consisted of 11 publications, most of them in English. Results: The data were categorized into three dimensions of care: educational (three articles), care (eight articles) and management (an article, which was also categorized as care). Educational: although nurses presented superficial and incomplete knowledge about incontinence, playful strategies were used for teaching. Assistance: the use of superabsorbent diapers and pads, 3\% dimethicone impregnated wipes, spray for the formation of polymer film for incontinence-associated dermatitis, pelvic musculature, urethral massage, bladder training, and eating habits modification were recommended. Gerencial: the quality of nursing care for the elderly with UI was evaluated through protocols, standards and Standard Operational Procedures (SOPs). Conclusion: There is a shortage of studies on the subject and it was evidenced that the nurse assumes an assistance role in urinary incontinence, although its knowledge is incipient.
\end{abstract}

DESCRIPTORS: Nursing; Urinary incontinence; Nursing care; Ostomy; Stomatherapy.

\footnotetext{
${ }^{1}$ Universidade Federal de Alfenas - Escola de Enfermagem - Curso de Graduação em Enfermagem - Alfenas/MG - Brazil.

¿Universidade Federal de Alfenas - Escola de Enfermagem - Programa de Pós-Graduação em Enfermagem - Alfenas/MG - Brazil. 3Pontifícia Universidade Católica de Campinas - Programa de Pós-Graduação lato sensu em Urgência e Emergência - Campinas/SP - Brazil. Autor correspondente: Silvana Maria Coelho Leite Fava | Rua Gabriel Monteiro da Silva, 700 - Centro | ZIP Code: $37130-000$ - Alfenas/ MG - Brazil | E-mail: silvanalf2005@yahoo.com.br Received: Jul 122018 | Accepted: Jan 132019
} 


\section{RESUMO}

Objetivos: Levantar na literatura o papel do enfermeiro no cuidado às pessoas com incontinência urinária (IU). Métodos: Revisão integrativa da literatura a partir das publicações no período de 2013 nas bases e bancos de dados: BDENF, LILACS, Web of Science, PubMed e SciELO, nos idiomas português, inglês e espanhol. A amostra foi composta por 11 publicações, sendo a maioria em inglês. Resultados: Os dados foram categorizados nas três dimensões do cuidado: educacional (três artigos), assistencial (oito artigos) e gerencial (um artigo, o qual também foi categorizado como assistencial). Educacional: embora os enfermeiros tenham apresentado conhecimento superficial e incompleto sobre a incontinência, foram utilizadas estratégias lúdicas para o ensino. Assistencial: foram recomendados o uso de fraldas e almofadas superabsorventes, lenços umedecidos e impregnados com dimeticona a 3\%, spray para formação de película de polímero para dermatite associada à incontinência, exercício da musculatura pélvica, massagem uretral, treinamento da bexiga e modificação dos hábitos alimentares. Gerencial: avaliou-se a qualidade do atendimento de enfermagem aos idosos com IU por meio de protocolos, normas e Procedimentos Operacionais Padrão (POPs). Conclusão: Há escassez de estudos na temática e evidenciou-se que o enfermeiro assume papel assistencial na incontinência urinária, embora seu conhecimento seja incipiente.

DESCRITORES: Enfermagem; Incontinência urinária; Cuidados de enfermagem; Estomia; Estomaterapia.

\section{RESUMEN}

Objetivos: Levantar en la literatura el papel del enfermero en el cuidado a las personas con incontinencia urinaria (IU). Métodos: Revisión integral de la literatura a partir de las publicaciones en el período del 2013 en las bases de datos: BDENF, LILACS, Web of Science, PubMed y SciELO, en los idiomas portugués, inglés y español. La muestra estuvo compuesta por 11 publicaciones, siendo la mayoría en inglés. Resultados: Los datos fueron categorizados en las tres dimensiones del cuidado: educativo (tres artículos), asistencial (ocho artículos) y gerencial (un artículo, el cual también fue categorizado como asistencial). Educativo: a pesar de que los enfermeros hayan presentado conocimiento superficial e incompleto sobre la incontinencia, fueron utilizadas estrategias lúdicas para la enseñanza. Asistencial: fue recomendado el uso de pañales y almohadillas super-absorbentes, toallas húmedas e impregnadas con dimeticona al 3\%, spray para formación de película de polímero para dermatitis asociada a la incontinencia, ejercicio de la musculatura pélvica, masería uretral, entrenamiento de la vejiga y modificación de los hábitos alimentarios. Gerencial: se evaluó la calidad del servicio de enfermería a los ancianos con IU por medio de protocolos, normas y Procedimientos Operativos Estándar (POPs). Conclusión: Hay escasez de estudios en la temática y se evidenció que el enfermero asume el papel asistencial en la incontinencia urinaria, a pesar de que su conocimiento sea incipiente.

DESCRIPTORES: Enfermería; Incontinencia urinaria; Cuidados de enfermería; Ostomía; Estomaterapia.

\section{INTRODUCTION}

Urinary incontinence (UI) is characterized as any involuntary loss of urine and is classified into three types: Stress UI (SUI), characterized by the complaint of urinary loss from any effort, sneezing or coughing; Urgent IU (UUI), which occurs due to urgency casting; and mixed UI (MUI), caused by the association of the two types of $\mathrm{UI}^{1}$.

The UI is an important public health problem, due to its high incidence rates and the negative impacts that can cause in the life of a person, compromising their quality of life, social interaction, daily life activities, and sexual life ${ }^{2}$.

It is important to consider that the prevalence and incidence rates of people with UI will be different, depending on the geographical and social context and the population characteristics, such as age, sex, physical and mental conditions. Thus, it is observed that the prevalence of people with UI is $27.6 \%$ in the female gender and $10.5 \%$ in the male gender ${ }^{3}$.

With regard to the causality of UI, it is evident that it may be associated with innumerable factors, such as advanced age; obstetric history and parity; gynecological surgeries; menopause; systemic arterial hypertension; therapy with diuretics and other medications; diabetes mellitus; obesity; smoking; alcohol; ingestion of caffeinated liquids; sedentary lifestyle; prostate hyperplasia; and sedentary lifestyle.

Nursing plays a fundamental role. The nurses' work develops from the reception, the establishment of the bond, proposing actions that minimize the damages, performing actions of promotion and prevention of aggravations and elaboration of protocols. 


\section{OBJECTIVES}

To collect, analyze and categorize a scientific production on the role of nurses in the care of people with UI and present the results found.

\section{METHODS}

It is an integrative review (IR) of the literature in which the following six steps were followed: identification of the theme and selection of the hypothesis; establishment of criteria for inclusion and exclusion of studies; definition of the information to be extracted from the selected studies and categorization of the studies; evaluation of included studies in IR; interpretation of results; and presentation of knowledge review/synthesis ${ }^{4}$.

Initially, the following guiding question was elaborated: what is the role of the nurse in the care of people with UI? The search for the studies was carried out online in databases and info banks. Inclusion criteria were defined as articles in the Portuguese, English and Spanish languages and published in the period from 2013 to 2017. This temporal cut is justified, considering the need to raise current nursing production on the subject and the knowledge gaps to subsidize new studies ${ }^{4}$.

The researches were carried out in databases and information banks of Nursing Databases (Base de Dados em Enfermagem - BDENF), Latin American and Caribbean Literature in Health Sciences (LILACS), Web of Science, National Library of Medicine National - Institute of Health (PubMed), which encompasses MEDLINE, and Scientific Electronic Library Online (SciELO), through the following descriptors: Enfermagem, Nursing, Enferméria, Cuidados de Enfermagem, Nursing Care, Atencion Enferméria, Estomia, Stomy, Incontinência Urinária e Incontinence Urinary, using the boolean operator "AND" between the descriptors ${ }^{4}$.

To obtain the data was used a validated instrument that includes the following data: year of publication; language; authorship; the purpose of the study; method; results; conclusions; levels of evidence; and knowledge gaps $^{5}$. To evaluate the levels of evidence was adopted pre-established criteria, which recommend a hierarchy of evidence according to the type of study ${ }^{6}$.
Subsequently, the information was analyzed through the reading of the selected articles. The data were then organized and categorized from recurrent themes, according to the dimensions of care, which allowed the achievement of the purposes of the present study ${ }^{7}$.

\section{RESULTS}

After the data were collected, the selection process of the studies that fit the inclusion criteria was performed, as shown in Fig. 1.

For the evaluation of the studies, the data were categorized as shown in Table 1. Most of the studies $36.37 \%(\mathrm{n}=4)$ were published in 2013, 63,3\% ( $\mathrm{n}=7)$ in the English language and 27.27\% $(\mathrm{n}=3)$ in Brazil.

Regarding the study design, it was observed that $27.27 \%(\mathrm{n}=2)$ adopted a qualitative approach. Regarding the levels of evidence, there was a predominance of 54.54\% ( $\mathrm{n}=6$ ) classified with the level of evidence VI, according to Table 2 .

Regarding the results, the data were grouped into categories of analysis, due to the similarity of the theme, and related to the three dimensions of care: educational, care and management.

\section{The first dimension of care: educational}

This category includes the themes related to education focused on prevention, treatment, and self-management, with emphasis on technologies, devices and the application of techniques and interventions. Thus, three articles were included, two of which addressed questions about prevention and treatment, while one discussed self-management, as we can see below.

A study developed with nurses evidenced that all had superficial knowledge about UI and also mentioned that they did preventive actions, but in reality, the performance was limited to the treatment and rehabilitation of people who sought care in the Health Strategy of the Family (Estratégia de Saúde da Família - ESF). It was also verified that only 


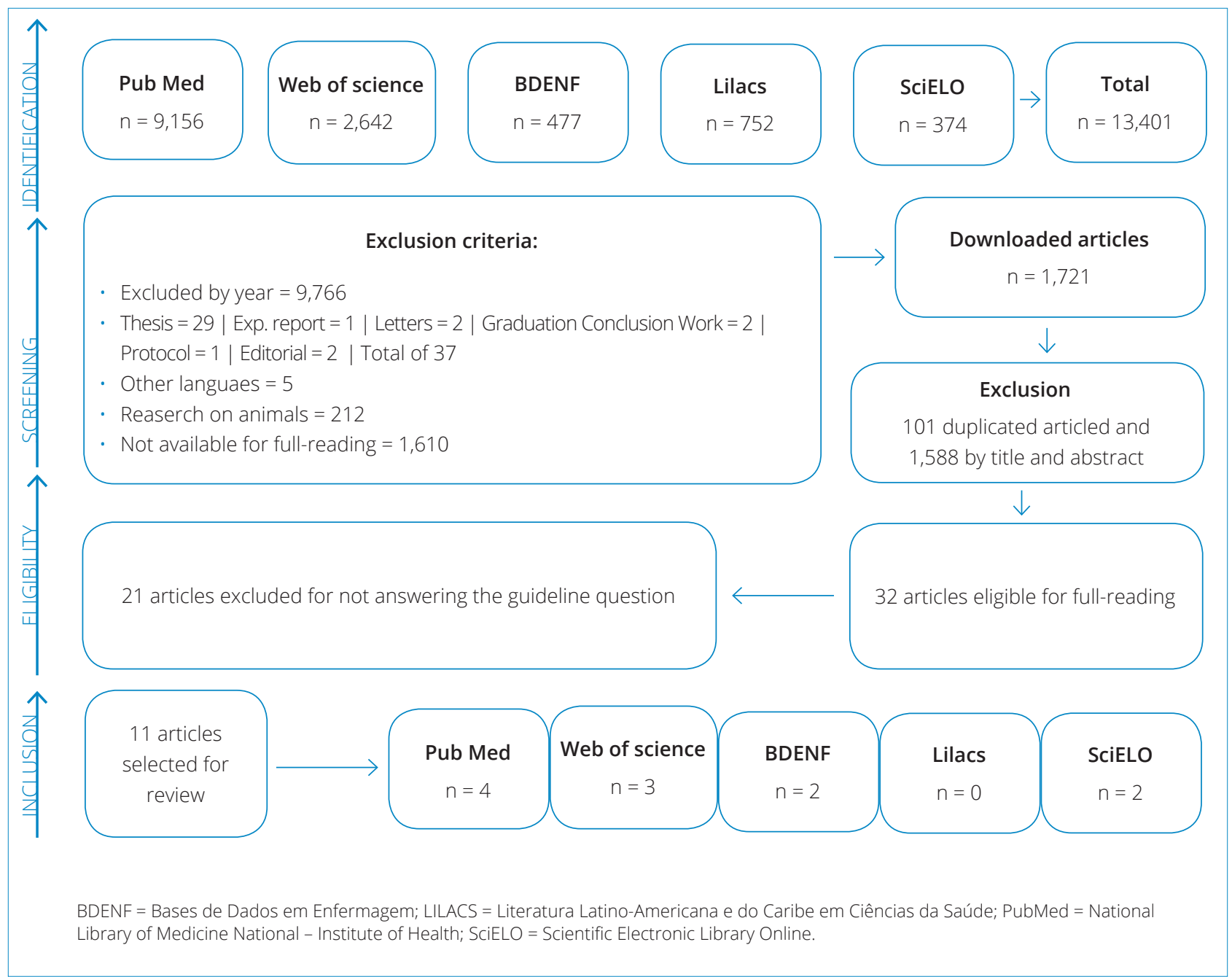

Figure 1. The flowchart selection process of articles. Adaptation of the flow diagram of the selection process of articles of the integrative review, according to the Preferred Reporting Items for Systematic Reviews and Meta-Analyzes (PRISMA).

one nurse was concerned with encouraging self-care in UI management ${ }^{8}$.

To identify knowledge and care practices about UI in elderly women and to develop the proposal of care for health promotion in primary care, an interview was conducted with 14 physiotherapists and 10 nurses in a health district of a capital city of southern Brazil. At the end of this study, the authors emphasized that the professionals' knowledge about UI prevention and treatment measures is of the utmost importance for the reception and the establishment of the link since it can facilitate and make people aware of their complaints and seek by treatment ${ }^{9}$.

In a UI self-management education program, playful activities were used, which were performed through songs, sketchbooks, colored stickers, and reflective discussions. These activities were designed to modify the risk factors of
UI, such as inadequate intake of diet and fluids; intestinal irregularity; overweight; smoking; physical inactivity; and weakened pelvic floor musculature. Exercises to strengthen the pelvic floor muscles were performed through Kegel exercises, yoga balls, and beach balls. The results showed that the participants were very satisfied with the effectiveness of the activities developed in the program, since, besides promoting the acquisition of knowledge, they minimized the severity of UI symptoms ${ }^{10}$.

\section{Second dimension of care: assistential care}

In the assistential care category, seven articles were selected, three of which contemplated the application of techniques/interventions and four focused on technologies, devices and other products, as mentioned below. 
Table 1. Characterization of studies on urinary incontinence according to title, periodical, year of publishing, language and country, 2013-2017, Alfenas / MG, Brazil.

\begin{tabular}{|c|c|c|c|c|}
\hline Title & $\begin{array}{c}\text { Periódico } \\
\text { (Tipo de publicação) }\end{array}$ & $\begin{array}{l}\text { Year of } \\
\text { publication }\end{array}$ & Idioma & Country \\
\hline $\begin{array}{l}\text { Assistência de enfermagem a idosos com } \\
\text { incontinência urinária }\end{array}$ & $\begin{array}{l}\text { Revista de Enfermagem UFPE } \\
\text { (Original article) }\end{array}$ & 2017 & $\begin{array}{l}\text { Portuguese/ } \\
\text { English }\end{array}$ & Brazil \\
\hline $\begin{array}{l}\text { Incontinência urinária em idosas: práticas } \\
\text { assistenciais e proposta de cuidado âmbito da } \\
\text { atenção primária de saúde }\end{array}$ & $\begin{array}{l}\text { Texto \& Contexto Enfermagem } \\
\text { (Original article ) }\end{array}$ & 2017 & Portuguese & Brazil \\
\hline $\begin{array}{l}\text { Tratamento da dermatite associada à } \\
\text { incontinência em idosos institucionalizados: } \\
\text { revisão integrativa }\end{array}$ & $\begin{array}{l}\text { Revista da Rede de } \\
\text { Enfermagem do Nordeste } \\
\text { (Review article) }\end{array}$ & 2013 & Portuguese & Brazil \\
\hline $\begin{array}{l}\text { Interventions for preventing and treating } \\
\text { incontinence-associated } \\
\text { dermatitis in adults }\end{array}$ & $\begin{array}{l}\text { Cochrane Database of } \\
\text { Systematic Reviews } \\
\text { (Review article) }\end{array}$ & 2016 & English/Spanish & Belgium \\
\hline $\begin{array}{l}\text { Medidas preventivas para evitar complicaciones } \\
\text { de salud derivadas del uso de sondajes } \\
\text { vesicales en pacientes lesionados medulares }\end{array}$ & $\begin{array}{c}\text { Enfermería Global } \\
\text { (Integrative review article) }\end{array}$ & 2013 & Spanish & Spain \\
\hline $\begin{array}{l}\text { Vaginal pessaries for pelvic organ prolapse } \\
\text { and urinary incontinence: a multiprofessional } \\
\text { survey of practice }\end{array}$ & $\begin{array}{l}\text { Jornal Internacional de } \\
\text { Uroginecologia } \\
\text { (Original article) }\end{array}$ & 2013 & English & $\begin{array}{l}\text { United } \\
\text { Kingdom }\end{array}$ \\
\hline $\begin{array}{l}\text { Incontinence care in nursing homes: a cross- } \\
\text { sectional study }\end{array}$ & $\begin{array}{l}\text { Journal of Advanced Nursing } \\
\text { (Original article) }\end{array}$ & 2015 & English & Austria \\
\hline $\begin{array}{l}\text { Twelve-year follow-up of conservative } \\
\text { management of postnatal urinary and faecal } \\
\text { incontinence and prolapse outcomes: } \\
\text { randomised controlled trial }\end{array}$ & $\begin{array}{l}\text { International Journal of } \\
\text { Obstetrics and Gynaecology } \\
\text { (Original article) }\end{array}$ & 2013 & English & $\begin{array}{l}\text { United } \\
\text { Kingdom/ } \\
\text { New Zeland }\end{array}$ \\
\hline $\begin{array}{l}\text { Treatment by a nurse practitioner in primary } \\
\text { care improves the severity and impact } \\
\text { of urinary incontinence in women. An } \\
\text { observational study }\end{array}$ & $\begin{array}{l}\text { Bio Med Central Urology } \\
\text { (Original article) }\end{array}$ & 2015 & English & Holand \\
\hline $\begin{array}{l}\text { The effect of a urinary incontinence self } \\
\text { management program for older women in } \\
\text { South Korea: A pilot study }\end{array}$ & $\begin{array}{l}\text { International Journal of Nursing } \\
\text { Sciences } \\
\text { (Original article) }\end{array}$ & 2015 & English & South Korea \\
\hline $\begin{array}{l}\text { Evaluation of the effectiveness of nurse-led } \\
\text { continence care treatments for Chinese } \\
\text { primary care patients with lower urinary tract } \\
\text { symptoms }\end{array}$ & $\begin{array}{l}\text { Plos One } \\
\text { (Original article) }\end{array}$ & 2015 & English & China \\
\hline
\end{tabular}

Adapted from Mendes et al. (2008).

A randomized clinical trial was conducted in the United Kingdom and New Zealand to determine the effects of the active conservative intervention (pelvic floor and bladder muscle training for postnatal UI) for a period of 12 years. The intervention was performed by a trained nurse who guided and conducted the pelvic and bladder exercises on three occasions: at 5, 7 and 9 months after delivery, so that the women were able to perform them over the course of 1 and 6 years. After 12 years, the women were contacted and the prevalence of UI was verified in four-fifths of the participants. In the end, the authors concluded that in the long term the intervention had no effect on the reduction of UI and that the result could have been better if meetings were held for continuous training of these exercises ${ }^{11}$.

A study conducted in the Netherlands aimed to assess the severity of UI in quality of life (QoL) of people referred by clinicians and attended by trained nurses. This research was performed using an instrument used to evaluate patients and, at the same time, to monitor their response to interventions over time. Then, a questionnaire was applied that aimed to know 
Table 2. Characterization of articles on urinary incontinence (UI) according to the authors, objective, type of study and levels of evidence, 2013-2017, Alfenas / MG, Brazil.

\begin{tabular}{|c|c|c|c|}
\hline Author & Objective & Type of study & $\begin{array}{l}\text { Evidences } \\
\text { level }\end{array}$ \\
\hline Bittencourt et al. & Descrever a assistência de enfermagem prestada ao idoso com IU & $\begin{array}{l}\text { Descritivo/ } \\
\text { qualitativo }\end{array}$ & $N-6$ \\
\hline Tomasi et al. & $\begin{array}{l}\text { Identificar o conhecimento e as práticas assistenciais sobre a IU em } \\
\text { mulheres idosas e desenvolver proposta de cuidado a essas mulheres } \\
\text { para a promoção da saúde no âmbito da atenção primária de saúde }\end{array}$ & $\begin{array}{l}\text { Descritivo- } \\
\text { qualitativo }\end{array}$ & $N-6$ \\
\hline Rosa et al. & $\begin{array}{l}\text { Identificar opções de intervenção terapêutica dos últimos } 5 \text { anos } \\
\text { para tratamento da dermatite associada à incontinência em idosos } \\
\text { institucionalizados }\end{array}$ & $\begin{array}{l}\text { Revisão } \\
\text { integrativa }\end{array}$ & $N-6$ \\
\hline Beeckman et al. & $\begin{array}{l}\text { Avaliar a eficácia de vários produtos e procedimentos para prevenir e } \\
\text { tratar a dermatite associada à incontinência em adultos }\end{array}$ & $\begin{array}{l}\text { Descritivo/ } \\
\text { qualitativo }\end{array}$ & N-6 \\
\hline Torres \& Agustias & $\begin{array}{l}\text { Determinar se certos tipos de sondas e técnicas são melhores para a } \\
\text { prevenção de complicações na IU em longo prazo }\end{array}$ & $\begin{array}{l}\text { Revisão } \\
\text { integrativa }\end{array}$ & $N-6$ \\
\hline Bugee et al. & $\begin{array}{l}\text { Investigar perspectivas multidisciplinares sobre pessários vaginais na } \\
\text { prática clínica para entender a organização de serviços de cuidados para } \\
\text { mulheres com essas condições }\end{array}$ & $\begin{array}{l}\text { Descritivo- } \\
\text { quantitativo }\end{array}$ & $N-6$ \\
\hline Mandl et al. & Descrever a qualidade do atendimento à incontinência em lares de idosos & Quantitativo & $\mathrm{N}-6$ \\
\hline Glazener et al. & $\begin{array}{l}\text { Determinar os efeitos em longo prazo (12 anos) de uma intervenção } \\
\text { conservadora conduzida por enfermeiros para a IU pós-natal }\end{array}$ & $\begin{array}{l}\text { Ensaio clínico } \\
\text { controlado } \\
\text { randomizado }\end{array}$ & $N-2$ \\
\hline Teunissen et al. & $\begin{array}{l}\text { Determinar a eficácia de introduzir uma enfermeira no cuidado da IU e } \\
\text { explorar as razões das mulheres por não completar o tratamento }\end{array}$ & $\begin{array}{l}\text { Ensaio clínico sem } \\
\text { randomização }\end{array}$ & $N-3$ \\
\hline Gagne et al. & $\begin{array}{l}\text { Desenvolver, implementar e avaliar a IU em um programa de autogestão } \\
\text { para mulheres residentes na comunidade de } 55 \text { anos ou mais com IU na } \\
\text { Coréia do Sul rural. }\end{array}$ & $\begin{array}{l}\text { Ensaio clínico sem } \\
\text { randomização }\end{array}$ & $N-3$ \\
\hline Choi et al. & $\begin{array}{l}\text { Avaliar se o cuidado de continência realizado por enfermeiras é eficaz na } \\
\text { melhoria dos resultados para pacientes adultos chineses com sintomas } \\
\text { do trato urinário inferior }\end{array}$ & $\begin{array}{l}\text { Ensaio clínico } \\
\text { randomizado }\end{array}$ & $\mathrm{N}-2$ \\
\hline
\end{tabular}

Adapted from Mendes et al. (2008).

the impacts that UI caused in their lives. The study was carried out in two moments; in the first, the researchers evaluated the participants' complaints and lifestyles and some interventions were performed; in the second, after 3 months, a reassessment was made in order to verify the results of the interventions ${ }^{12}$.

At the end of the study, the authors found that there was a significant improvement in patients' complaints regarding social, emotional and well-being dimensions, while no significant results were observed regarding travel and mobility. In addition, the existence of a correlation between the foods ingested by the participants and the UI was observed, with the intake of 3.6 cups per day of caffeine and excessive alcohol consumption were important factors that could negatively affect the UI. Regarding nurses' performance, the results of this study pointed out that, when these professionals are properly trained, they may be able to influence the improvement of QoL and increase the motivation of people with UI, thus contributing to a more effective treatment ${ }^{12}$.

The muscular exercises, through contraction and relaxation of the pelvic floor musculature aiming at the improvement of stiffness, strength, endurance, coordination and muscle function; diet modification through nocturnal water restriction and reduced consumption of alcohol and caffeine-containing liquids; and bladder training, in which the toilet could not be used for a certain period of time, so that the interval between one urination and another was increased, are interventions performed by nurses who have improved the clinical outcomes of people with UI and improvement in quality of life ${ }^{13}$.

The superabsorbent diapers, the sprays used for the formation of polymer film, and the moist tissues 
impregnated with 3\% dimethicone were effective strategies for the prevention and treatment of UI-associated dermatitis ${ }^{14}$.

Water and soap had poor performance in the prevention and treatment of UI-associated dermatitis. Calmoseptin with $20 \%$ zinc oxide in its composition indicated improvement in the treatment of dermatitis. The Cavilon and another barrier shield were being tested in some studies and so it is not yet known whether they are effective or not ${ }^{15}$.

Regarding the types of catheters and the best catheterization techniques for the prevention of UI complications, there were few studies that showed that the incidence of urinary tract infection could improve with some type of technique, strategy or probe. The importance of an individualized care plan to identify the appropriate frequency of catheterization was emphasized, and that intermittent bladder catheterization offers more advantages than permanent catheterization, greater selfcare and independence of individuals, reduced risk of common complications associated with the catheter reduction of the need for instruments and artifacts, such as a drainage bag, greater freedom of expression for sexuality and the possibility of reducing urinary symptoms (frequency, urgency, incontinence) between each catheterization interval ${ }^{16}$.

In clinical practice, the vaginal pessary is used, which is a polyurethane sponge made in three sizes, placed in the vagina with the aid of an applicator. The nurses or physiotherapists claimed they had not been trained to handle the pessaries, while physicians were significantly more likely to report pessary care ${ }^{17}$.

\section{The third dimension of care: managerial}

Only one article was found in this theme, which was also categorized as care. The study carried out in 16 nursing homes described the quality of UI care in nursing homes. A number of structural and human indicators that interfere with the assistance and functionality of institutions were evaluated.

Regarding the availability of structural indicators at an institutional level, it was observed that the guidelines for treatment and the specialist item used to update the guidelines were frequent in 10 institutions (62\%).
In the indicator "protocols for managing incontinence products", 15 (93\%) of the nursing homes adopted this policy in its quality standard. Information leaflets dealing with UI were present only in three institutions (18.75\%) and, regarding the availability of the structural indicators at the sector/wing level, it was evidenced that only six (36\%) had a nursing professional to the elderly people affected by UI. Regarding nursing interventions, the results showed that $85 \%$ of people with UI used disposable cushions and another $51 \%$ adopted behavioral habits to reduce their urinary losses. Other indicators, such as medication evaluation, diaper changes, and pelvic muscle training appeared as rarely used interventions ${ }^{18}$.

Thus, it was found that the results of this study provide an initial view of the quality of incontinence care in relation to structure, process level and outcome indicators in Austrian asylum and concluded that structural indicators are limited in Austrian nursing homes. The prevalence of all types of incontinence was still high, which necessitates the need for improvements in the care of incontinence in Austrian asylum, as an update course on the subject ${ }^{18}$.

\section{DISCUSSION}

Regarding the educational dimension, this should be understood as a practice aiming at improving the living and health conditions through guidance to individuals and families ${ }^{19}$.

That said, people need to gain autonomy to identify and use the ways and means to preserve and improve their lives. This process must involve the negotiation between the perspective of health professionals adjusted to the needs and priorities defined by the patient self ${ }^{20}$.

Transposing this concept to care for people with UI, it is fundamental to consult the nursing to know the needs, in order to propose educational actions that can prevent, treat and improve their complaints, so that there are behavioral changes towards the improvement of the quality of life. To do so, it is necessary for the nurse to follow scientific and technological evolution, adopt strategies and skills to transform and means to make educational actions easier.

Some nurses interviewed demonstrated the importance of guiding care related to healthy eating 
habits, correct use of medications, control of chronic diseases, measures to prevent constipation, measures to avoid smoking and alcohol, among others. At the nurses' conception, these risk factors could prevent and/ or minimize the symptoms. It is believed that there is a need to invest more in the training of professionals so that the health of the elderly is addressed in an integral way, promoting improvement in the well-being and quality of life ${ }^{9}$.

It was noticed that the educational activities developed by the nurses in relation to the UI are based on actions of promotion and prevention of diseases and that there is a lack of actions of prevention and promotion in health. And yet, of the 13 nurses involved in care, only one brought the importance of promoting self-care ${ }^{8}$.

For the development of educational actions to work on the UI theme, music therapy was used, with popular songs that addressed health prevention, making education sessions fun and effective, out of the routine of papers and pencils ${ }^{10}$.

The assistance dimension is characterized by the implementation of nursing care actions, having as an intervention object the care needs, and its purpose is to provide care from a comprehensive perspective.

It should be emphasized that the nurse has to appropriate four components to provide specialized assistance in the UI approach: philosophical theorist, conceptual theorist (incontinence pathophysiology); foundations for taxonomic care [American Nursing Diagnosis Association (Nanda), Nursing Interventions Classification (NIC) and Nursing Outcomes Classification (NOC) and legal [Nursing Care Systematization (SAE) and nursing process] basis. In this understanding, the related factors and defining characteristics enable the investigation and determination of the nurse's behavior in the care of the person with UI or at risk of developing $\mathrm{it}^{21}$.

The exercises of the pelvic muscles and the training of the bladder were used as a nursing intervention. Although the results were not satisfactory, they attributed failure to lack of longitudinality in the participants' follow up ${ }^{11}$.

On the other hand, a study found positive results with the interventions performed by nurses through exercises and training and the modifications of daily habits. They also attributed, to the satisfactory results, the relationship that was established between the participants, mainly between the women and the professionals, since the participants found space to express their complaints related to $\mathrm{UI}^{13}$.

However, similar results were found by the fact that the interventions through exercises and training were effective and how important the nurses in this process ${ }^{12,13}$.

The results of the intervention studies revealed that the exercises and training for UI are effective, as well as the actions developed by the nurses and the importance of the reception so that people can find spaces for dialogue and to express their needs. It should be noted that the three studies are international and point to an important knowledge gap at the national level.

In Brazil, for more than 10 years, the Pelampic Floor Rehabilitation Program (PRAP) has been carried out at the Unicamp Nursing School, with the purpose of training nurses and nursing undergraduates to act with this practice, thus providing, quality and resolutive assistance. Currently, there are other professionals, physiotherapists and physical educators involved in the project. ${ }^{22}$.

Studies have found that superabsorbent diapers, 5\% dimethicone wipes, polymer film spray and 20\% Calmoseptin with zinc oxide have demonstrated good efficacy in the treatment of UI-associated dermatitis ${ }^{14,15}$.In contrast, soapy water is not suitable for use in dermatitis, and although Cavilon has been used in the treatment of dermatitis, the results of the study using this product have not yet been completed $^{15}$.

However, it should be noted that in both reviews the selected studies were international and of low evidence, which demonstrates the need for studies developed by nurses and with a high level of evidence to test the best products for the prevention and treatment of UI associated dermatitis and support clinical practice.

Still, regarding the use of technologies, devices, and products, a study was inconclusive regarding the types of probes and techniques for the prevention of UI. The author concluded the advantages concerning the incentive to selfcare and reduction of the risk of infection of the intermittent probing in relation to the permanent probe ${ }^{16}$.

One study reveals that although pessaries are used and recommended for UI treatment, nurses still do not feel able to use this device, while physicians have demonstrated greater safety, followed by physiotherapists ${ }^{17}$.

The results of the studies revealed an important knowledge gap and the need to develop clinical research 


\section{CONCLUSION}

on the management of UI performed by nurses on the evaluation of product efficacy and the best techniques to minimize its occurrence, mainly related to the materials and the technique of the bladder catheter, given that it is a nursing exclusive technique.

Regarding the managerial dimension, there was a shortage of studies, although management is an important dimension that articulates with the other dimensions of care.

The study held in the managerial dimension found, as important indicators of the quality of care, the availability and maintenance of the cushions and the protectors of chairs and beds, the information leaflets that allowed the institutionalized people to understand their signs, symptoms, causes, and ways of treating, times for visits to the bathroom, nurse availability and protocols for use of incontinence products and nursing records ${ }^{18}$.

Nurses, to better manage their daily activities, have adopted, as important tools, protocols and Standard Operational Procedures (SOPs). This instrument, based on technical, scientific and legal knowledge, allows the standardization of assistance since it regulates, bases, standardizes, organizes and qualifies any activity provided for efficiency and effectiveness. It is also important to consider that continuing education is seen as a strategy that allows the development of people so that the goals of the institution are achieved.

Of the 11 articles selected for this review, only one was concerned with evaluating the indicators related to the assistance of professionals to people with UI. It is also perceived the existence of a dichotomy between management and care, which makes the dimensions of care counterproductive ${ }^{13}$.

Although UI is considered an important public health issue, in Brazil, there is little research on the subject, mainly by nurses. There is, therefore, an important gap to be filled with studies with greater methodological rigor and high levels of evidence that make it possible to sustain nurses' clinical practice in order to promote, prevent, treat and rehabilitate UI.
It is concluded that the knowledge of nurses in the UI is incipient and that this tends to develop their actions in the assistance dimension with predominance in the treatment and recovery. This reality points to an important gap. It is expected that the nurse acts more and more assertively in health education, with preventive actions. Thus, financial expenses, working time and emotional exhaustion would be minimized.

Regarding the limitations of this study, it was observed that most of the articles analyzed were of descriptive methodology, and therefore, classified with a low level of evidence. In addition, there was a shortage of publications regarding the devices offered in the market to attend the public with UI status, either in the prevention, rehabilitation or improvement of the quality of life, which makes it impossible for nurses to standardize based on levels of evidence on the best products and techniques for UI management.

Given the scarcity of studies and the incipient knowledge of nurses about this important condition, it is suggested that studies with high levels of evidence should be carried out, aswell as the inclusion of the subject in undergraduate courses and the development of programs in primary health care.

\section{CONTRIBUTION OF AUTHORS}

Conceptualization, Fava SMCL; dos Reis SC; Oliveira TS; Dias JF and Sanches RS; Methodology, Fava SMCL; dos Reis SC; Oliveira TS; JF Days; Sanches RS and Dazio EMR; Research, Fava SMCL; dos Reis SC; Oliveira TS and Dias JF; Writing - First version, Fava SMCL; dos Reis SC; Oliveira TS; JF Days; Sanches RS and Dazio EMR; Writing - Review \& Editing, Fava SMCL; Sanches RS and Dazio EMR; Resources, Fava SMCL; Supervision, Fava SMCL.

\section{REFERENCES}

1. International Continence Society. Recommendations of the International Scientific Committee: evaluation and treatment of urinary incontinence, pelvic organ prolapse and faecal incontinence. $4^{\text {a }}$ International Consultation on Incontinence; 2009. [cited 10 jan 2018]. Available at: http://www.ics.org/ Publications/ICl 4/files-book/recommendation.pdf 
2. Bolina AF, Dias FA, Santos NMF, Tavares DMS. Incontinência urinária autorreferida em idosos e seus fatores associados. Rev RENE. 2013;14(2):49-55.

3. Santos KFO. Qualidade de vida de pessoas idosas com incontinência urinária [dissertação]. João Pessoa (PB): Universidade Federal da Paraíba, Centro de Ciências da Saúde; 2013.

4. Mendes KDS, Silveira RCCP, Galvão CM. Revisão integrativa: método de pesquisa para a incorporação de evidências na saúde e na enfermagem. Texto Contexto Enferm. 2008;17(4):758-64.

5. Ursi ES. Prevenção de lesões de pele no perioperatório: revisão integrativa da literatura. Rev Latino-am Enfermagem. 2005;14(1):124-31.

6. Melnyk BM, Fineout OF. Making the case for evidence-based practice. Evidence-based practice in nursing e healthcare. A guide to best practice. In: Melnyk BM, Fineout-Overholt E. Evidence-based practice in nursing \& health care. A guide to best practice. Philadelphia: Lippincott Willians \& Wilkins; 2005. p. 3-24.

7. Hausmann M, Peduzzi M. Articulação entre as dimensões gerencial e assistencial do processo do trabalho do enfermeiro. Texto Contexto Enferm. 2009;18(2):258-65.

8. BittencourtJR, Lopes IR, JúniorJJS, Oliveira NRR, Teles MAB, Luna PMR. Assistência de enfermagem a idosos com incontinência Urinária. Rev enferm UFPE. 2017;11(2):966-72. https://doi. org/10.5205/reuol.10263-91568-1-RV.1102sup201712

9. Tomasi AVR, Santos SMA, Honório GJS, Locks MOH. Incontinência urinária em idosas: práticas assistenciais e proposta de cuidado âmbito da atenção primária de saúde. Texto contexto - enferm. 2017;26(2):e6800015. https://doi. org/10.1590/0104-07072017006800015

10. Gagne JC, So A, Wu B, Palmer MH, Connell ESMC. The effect of a urinary incontinence self-management program for older women in South Korea: a pilot study. Int J Nurs Sci. 2015;2(1):39-46. https://doi.org/10.1016/j.ijnss.2015.01.002

11. Glazener CMA, MacArthur C, Hagen S, Elders A, Lancashire R, Herbison GP et al. Twelve-year follow-up of conservative management of postnatal urinary and faecal incontinence and prolapse outcomes: randomised controlled trial. BJOG. 2013;121(1):112-20.

12. Teunissen DTAM, Stegeman MM, Bor HH, Langro-Janssen TALM. Treatment by a nurse practitioner in primary care improves the severity and impact of urinary incontinence in women. BMC Urol. 2015;15:51. https://doi.org/10.1186/ s12894-015-0047-0

13. Choi EPH, Chin WY, Lam CLK, Wan EYF, Chan AC, Chan KHY. Evaluation of the effectiveness of nurse-led continence care treatments for Chinese primary care patients with lower urinary tract symptoms. Plos One. 2015;10(6);e0129875. https://doi.org/10.1371/journal.pone.0129875

14. Rosa LHT, Souza CM, Lima CHL, Boggiod ESB, Santose FC, Carbonif $C$ et al. Prevalência da incontinência urinária em idosos de Porto Alegre-RS. Rev Geriatr Gerontol. 2014;9(2):112-7.

15. Beeckman D, Damme NV, Schoonhoven L, Lancker AV, Kottner J, Beele $\mathrm{H}$. et al. Interventions for preventing and treating incontinence-associated dermatitis in adults. Cochrane Database Syst Rev. 2016;11. https://doi. org/10.1002/14651858.CD011627

16. Torres A, Angustias M. Medidas preventivas para evitar complicaciones de salud derivadas del uso de sondajes vesicales en pacientes lesionados medulares. Enferm glob. 2013;12(30): 370-78.

17. Bugge C, Hagen S, Thakar R. Vaginal pessaries for pelvic organ prolapse and urinary incontinence: a multiprofessional survey of practice. Int Urogynecol J. 2013;24(6):1017-24. https://doi.org/10.1007/s00192-012-1985-7

18. Mandl M, Halfens RJ, Lohrmann C. Incontinence care in nursing homes: a cross-sectional study. J Adv Nurs. 2015;71(9):2142-52. https://doi.org/10.1111/jan.12676

19. Pressoto GV, Ferreira MBG, Contim D, Simões ALA. Dimensões do trabalho do enfermeiro no contexto hospitalar. Rev RENE. 2011;15(5):760-70. https://doi. org/10.15253/2175-6783.2014000500005

20. Lopes APF. Cuidado e empoderamento: a construção do sujeito responsável por sua saúde na experiência do diabetes. Saude soc. 2015;24(2):486-500. https://doi. org/10.1590/S0104-12902015000200008

21. Martins NA. Pessoas idosas e incontinência urinária: trajetória da proposição de um modelo de sistematização da assistência especializada em enfermagem [dissertação]. Juiz de Fora (MG): Universidade Federal de Juiz de Fora, Programa de Pós-Graduação em Enfermagem; 2014.

22. Lopes MHBM, Costa JN, Lima JLDA, Oliveira LDR, Caetano AS. Programa de reabilitação do assoalho pélvico: relato de dez anos de experiência. Rev Bras Enferm. 2017;70(1):219-23. https://doi.org/10.1590/0034-7167-2016-0257 